\title{
Influence of Crop Establishment Methods on Crop Water Productivity and Profitability in Rice-Wheat Systems under Eastern Indo Gangetic Plains
}

\author{
S.K. Tomar ${ }^{1}$, S.N. Singh ${ }^{2}$, A.P. Rao ${ }^{3}$, R.K. Naresh ${ }^{4}$, V.K. Sharma ${ }^{5}$, Sudhanshu Singh ${ }^{5}$, \\ S.K. Bargaha ${ }^{6}$, Shailesh K. Singh ${ }^{7}$, Ashok Pandey ${ }^{8}$, J.P. Singh ${ }^{9}$ and R.V. Singh ${ }^{2}$ \\ ${ }^{1}$ K V K Belipar, Gorakhpur; ${ }^{2} K$ V K, Basti; ${ }^{3}$ Directorate of Extension; ${ }^{6} K$ V K Ayodhya; \\ ${ }^{7}$ K V K Amethi; ${ }^{8}$ K V K Siddharthnagar; ${ }^{9} \mathrm{~K}$ V K Azamgarh \\ Narendra Dev University of Agriculture \& Technology Kumarganj, Ayodhya (U.P.), India \\ ${ }^{4}$ Department of Agronomy, SardarVallabhbhai Patel University of Agriculture \& Technology, \\ Meerut, (UP), India \\ ${ }^{5}$ Division of Soil Science, Indian Agricultural Research Institute New Delhi, India
}

*Corresponding author:

\section{Keywords}

Crop establishment methods, Drum seeder, Zero tillage, Profitability, RiceWheat system

Article Info

Accepted: 04 May 2019 Available Online: 10 June 2019

\section{A B S T R A C T}

Rice-Wheat cropping system pre-dominated in the India covering an area of about 10.5 million hectare. Adverse effect of continuous puddling in rice field forced scientists to search for other methods of rice establishment like direct seeding; machines transplanted and dry seeding with ZT machine and wheat by zero tillage etc. In a 3-year study, we assessed the effects of crop establishment methods in participatory mode on farmers' field through on farm on productivity and profitability in a rice-wheat $(\mathrm{RW})$ system at Basti, Siddharthnagar and Gorakhpur district of U.P. Result of the study revealed that rice sown with drum seeder in puddled condition gave highest grain yield among the rice establishment methods tested. Rice sowing with drum seeder yield was increased 4.1, 11.4 and $25.6 \%$ over farmer practice in Basti, Siddharthnagar and Gorakhpur locations, respectively. Wheat planted in Rice (UPMTP) - Wheat (ZT) gave 4.6 tha $^{-1}$ grain yields than FP. Zero tillage wheat sown obtained 10.4, 13.5 and $12.5 \%$ higher yield over the farmers practice in Basti, Siddharthnagar and Gorakhpur locations. Treatment unpuddled mechanical transplanted rice and zero tillage wheat recorded highest rice equivalent yield $9.9 \mathrm{t} \mathrm{ha}^{-1} \mathrm{yr}^{-1}$. Treatments rice (DSR) - wheat (ZT) followed by rice (DMS) - wheat (ZT) and rice (UPMTP) - wheat (ZT) obtained higher net return and B: C ratio. However, compared with traditional practice of cultivation farmers much convinced with rice sown either dry direct seeded or mechanical transplanted drum seeding and wheat by zero tillage technology, especially in terms of independency of agricultural labourers, yield potential and benefit-cost ratio. Results from this study revealed that conventionally tilled (CT) and transplanting of rice could be successfully replaced by adoption of the profitable DSR wheat ZT in -rice-wheat system. 


\section{Introduction}

Rice and wheat are staple food crops of the world cultivated on an area around $370.4 \mathrm{~m}$ ha. A large proportion of world population relies on rice and wheat for daily caloric intake, income and employment. Rice-wheat cropping system is one of the major cropping systems in South Asia and is practiced in 14 million hectares area (Singh et al., 2010) providing food for more than 400 million people. The rice-wheat production systems are fundamental to employment, income, and livelihoods for hundreds of millions of rural and urban population of South Asia (Saharawat et al., 2010). This system covers about 10.5 million hectares in India contributes $26 \%$ of total cereal production, $60 \%$ of total calorie intake and about $40 \%$ of the country's total food basket (Sharma et al., 2015). In India rice occupies nearly 44.1 million hectares area, 105.5 million tonnes total production with a productivity of 2291 $\mathrm{kgha}^{-1}$ productivity for the year 2014-15 (Anonymous, 2016). Rice is the most important staple food in Asia, where more than $90 \%$ of the world ${ }^{\text {ee }} \mathrm{s}$ rice is grown and consumed.

Tillage is one of the basic inputs of crop production, actually tillage alters the rhizosphere environment by modifying most of the physical properties of the soil, viz. bulk density and soil strength, hydraulic conductivity and aggregates stability, infiltration rate and porosity due to formation, destruction and rearrangement of soil particles and aggregates and alternation in clod size distribution (Kurothe et al., 2014). In the conventional systems involving intensive tillage, there is gradual decline in soil organic matter by quicker oxidation and burning of crop residues causing pollution, greenhouse gases emission, and loss of valuable plant nutrients. However, the extent of the impacts of tillage is variable depending upon the inherent soil characteristics and climatic conditions. Puddling effects adversely on soilphysical condition for establishment and raising the succeeding crops (Bhatt et al., 2015). This practice is water, capital and energy intensive, and deteriorates soil health (Das et al., 2014).

Puddling leads to the formation of a hard-pan at shallow depths deteriorates soil physical properties and delays planting of a succeeding wheat crop. Timely planting of wheat is crucial as yield reductions of $1-1.5 \%$ per day occur for each day after the optimum sowing date, November 15 in the IGP (Jat et al., 2009). Therefore, it is imperative that alternate method of growing crops that are more water efficient and less labour intensive to be developed to enable farmers to produce more with less cost of production. Huge labours are needed to accomplish transplanting of rice seedlings and mostly it is delayed to a greater extent due to unavailability of adequate labours during transplanting peak. Thus, late planted rice takes more time to reach the maturity, which not only reduces the rice yield but also delays sowing of succeeding crop particularly wheat but direct seeding of rice can reduce the labour and water requirement, shorten the duration of crop by 7-10 days and provide comparable yield with transplanted rice (Mishra et al., 2012). In plains of Eastern India, sowing of wheat gets delayed due to wet condition after rice harvesting which takes much time to come in working condition, also tillage in such soils require more time, labour and energy. On the other hand, zero tillage minimizes loss on account of delayed sowing as it advances the wheat sowing by $10-15$ days and also saves the time and cost involved in field preparation. Conventional methods of wheat sowing, which requires excessive tillage delays the sowing and reduce the yield, but the same can be accomplished efficiently with use of 
improved machines, viz. zero till ferti-seed drill and rotavator etc. to save the time, fuel, energy and cost (Bohra and Kumar, 2015). Therefore, the present investigation was envisaged with an objective to identify a suitable combination of crop establishment method for maximum productivity and profitability from rice -wheat cropping system.

\section{Materials and Methods}

\section{Experimental site}

A farmers' participatory field experiment was established in the year 2015 at Siddharthnagar, Gorakhpur and Basti districts of Uttar Pradesh under Narendra Dev University of Agriculture \& Technology, Ayodhya, with rice (Oryza sativa L.)-Wheat (Triticum aestivum L.) cropping system. The region has a semi-arid to sub-humid climate with an average annual temperature of 19.3 ${ }^{0} \mathrm{C}$.The highest mean monthly temperature $\left(40.7{ }^{0} \mathrm{C}\right)$ is recorded in May, and the lowest mean monthly temperature $\left(4.5^{\circ} \mathrm{C}\right)$ is recorded in January. The average annual rainfall is about 1050 to $1080 \mathrm{~mm}$ of which around $87 \%$ is acknowledged for the duration of monsoon period. Remaining $13 \%$ rainfall is received during the non-monsoon period in the wake of western disturbances and thunder storms. The experimental soils sandy loam/ loam in texture having $\mathrm{pH}$ (7.80-8.60), EC $\left(0.16-0.38 \mathrm{dSm}^{-1}\right)$, organic carbon (0.27 -0.29 $\%$, available $\mathrm{N}(102-252 \mathrm{~kg} / \mathrm{ha})$, available $\mathrm{P}_{2} \mathrm{O}_{5}$ (10.0-26.5 kgha ${ }^{-1}$ ) available K (110-265 $\mathrm{kgha}^{-1}$ ), available S (10.3-23.5 $\left.\mathrm{kgha}^{-1}\right)$, DTPAextractable $\mathrm{Zn}\left(0.46-.62 \mathrm{mgkg}^{-1}\right)$, Fe (2.90$\left.6.25 \mathrm{mgkg}^{-1}\right), \mathrm{Mn}\left(3.44-8.60 \mathrm{mgkg}^{-1}\right)$ and $\mathrm{Cu}$ $\left(0.65-1.58 \mathrm{mgkg}^{-1}\right)$ and available B (0.20-0.32 $\left.\mathrm{mgkg}^{-1}\right)$.

\section{Experimental design and management}

A comprehensive description of unlike tillage systems is essential to compare effect of tillage on environmental concert (Derpsch et al., 2014). The experiment was laid out in farmers' participatory mode and farmer is treated as replication. The experimental design was randomized block design keeping five crop establishment methods viz., $\mathrm{T}_{1}=$ manual transplanted rice- wheat conventional practices (CTPR) $-(\mathrm{CSW}) \mathrm{FP} ; \mathrm{T}_{2}=$ puddled direct wet seeded rice by drum seeder-wheat zero tillage (PDSR)-(ZTW); $\mathrm{T}_{3}=$ unpuddled direct seeded rice by zero till cum ferti seed drill - wheat zero tillage (DSR)-(ZTW); $\mathrm{T}_{4}=$ unpuddled rice transplanted by machine wheat zero tillage (UMTPR)- (ZTW) and $\mathrm{T}_{5}=$ unpuddled rice transplanted by machinewheat roto till (UMTPR) - (RTW). A uniform dose of $150 \mathrm{~kg} \mathrm{~N}, 60 \mathrm{~kg} \mathrm{P}_{2} \mathrm{O}_{5}, 40 \mathrm{~kg} \mathrm{~K}_{2} \mathrm{O}$ and $5 \mathrm{~kg} \mathrm{Zn} \mathrm{ha}{ }^{-1}$ was applied for rice and wheat crops in all the treatments through urea (46\% $\mathrm{N})$, DAP $\left(18 \% \mathrm{~N}\right.$ and $\left.46 \% \mathrm{P}_{2} \mathrm{O}_{5}\right)$, muriate of potash $\left(60 \% \mathrm{~K}_{2} \mathrm{O}\right)$ and $\mathrm{ZnSO}_{4}$ respectively. Half of total nitrogen and full dose of $\mathrm{P}_{2} \mathrm{O}_{5}$, $\mathrm{K}_{2} \mathrm{O}$ and $\mathrm{Zn}$ were applied to rice crop as basal (sowing/transplanting) and remaining half dose of nitrogen in the form of urea was top dressed in two equal splits, at active tillering and panicle initiation stage, respectively. Rice variety NDR 3112 and wheat variety HD 2967 was used for sowing / transplanting with recommended seed rate.

Rice was transplanted on June $20^{\text {th }}$ to $27^{\text {th }}$ and wheat was sown on November $15^{\text {th }}$ to $20^{\text {th }}$ during experimentation. The herbicide glyphosate $\left(1 \mathrm{~kg} \mathrm{ha}^{-1}\right)$ was applied in zero-till treatments before the seeding to knock down the weeds, pendimethalin $1 \mathrm{~kg} \mathrm{ha}^{-1}$ (preemergent) $f b$ bispyribac $25 \mathrm{~g} \mathrm{ha}^{-1}$ at 20 DAS/DAT were applied by using knap sack sprayer with flat fan nozzle for weed control in rice and for wheat, Sulfosulfuran $33 \mathrm{~g}+$ $20 \mathrm{~g} / \mathrm{ha}$ metsulfuron was applied at 30 DAS. The crop was harvested at maturity stage. First, the border rows were harvested and separated. Later, crop from net plot was harvested and sun dried. The harvested material from each net plot was carefully 
bundled, tagged and brought to the threshing floor separately. Threshing was done plot wise and grains were cleaned, dried and weighed separately for each net plot and computed in terms of $\mathrm{kg} \mathrm{ha}^{-1}$ at $14 \%$ moisture level. The straw yield was also recorded plot wise after sun drying and computed to $\mathrm{kg}$ ha ${ }^{1}$.Test weight $(\mathrm{g})$ of 1000 -seeds from each plot was recorded. The economics are calculated viz. Gross and return $\left(\square\right.$ ha $\left.^{-1}\right)$ and B: C ratio separately. The data recorded for different crop parameters were analysed using analysis of variance (ANOVA) technique (Gomez and Gomez, 1984) for complete randomized block design. Where ANOVA was significant, the treatment means were compared using LSD procedure at $5 \%$ level of significance.

\section{Results and Discussion}

\section{Effect of crop establishment methods on rice crop}

Treatment $\mathrm{T}_{4}$ was recorded significantly higher effective tillers $/ \mathrm{m}^{2} 363$ and filled grains / panicle 45 as compared to other rice establishment methods during experimentation. In general higher 1000 grain weight was recorded under puddled field rice sown or transplanted when rice sown/transplanted after either conventional or mechanical (Table 1). Treatment $\mathrm{T}_{4}$ unpuddled rice transplanted by drum seeder was recorded significantly highest grain yield at Basti, Gorakhpur and Siddharthnagar location, respectively over all other crop establishment practices except unpuddled rice sown by machine. Machanical transplanting of rice in unpuddled, puddled condition and dry direct seeded method of crop establishment were at par but yielded significantly higher over conventional method of transplanting (FP) at Gorakhpur and Siddharthnagar location but at Basti difference was not makeable. On the basis of mean yield across the district crop establishment method of rice sown with drum seeder recorded highest grain yield followed by mechanical transplanting in puddled condition, mechanical transplanting in unpuddled condition and dry direct seeding by ZT machine using stale bed technique. Higher grain yield in drum seeder sown crop might be due to optimum plant population and depth of sowing with appropriate other yield attributes. Poor performance in conventional method of transplanting (FP) was due to less plant population $/ \mathrm{m}^{2}$. Similar or high yield attributes and yield of rice were reported earlier by many researchers [Ladha et al., (2009) and Jat et al., (2009) Yadav et al., (2014)].

\section{Effect of crop establishment method on wheat}

Different sowing method of wheat had significant variation in yield attributes viz. effective tillers $/ \mathrm{m}^{2}$, number of grains /spike, 1000 grain weight and grain yield (Table 2). Wheat sown by zero tillage after conventional puddled transplanted rice recorded highest grain yield 44.5, 46.3 and $47.5 \mathrm{q} / \mathrm{ha}$ at Basti, Gorakhpur and siddharthnagar location followed by zero till wheat sown after dry direct seeded rice. Irrespective of various crop establishment methods, zero till sown wheat by gave $5.93 \%$ higher yield over conventional sowing wheat. Higher grain yield under zero till sown wheat were due to more number of effective tillers, grain /panicle and test weight. The possible reason for higher yield attributes and grain yield in zero till sown wheat might be due to the effect in better equilibrium between macro and micro-porosity leading to increased root biomass in the surface soil layer. Conventional tillage had obtained the lowest wheat yield because wheat crop suffered the ills of puddling in preceding rice crop resulting in poor rooting due to soil compaction and poor aggregation as reported by other researchers in the region (Jat et al., 
2009; Kumar and Ladha, 2011 and Gathala et al., 2011).

\section{Effect of crop establishment method on system productivity}

Total productivity of rice -wheat cropping was calculated in rice equivalent yield (REY) for the treatment (Table 3). Rice transplanted by machine in unpuddled condition $f b$ zero till wheat sown recorded highest REY $\left(9.9 \mathrm{t} \mathrm{ha}^{-1}\right.$ $\mathrm{yr}^{-1}$ ). Treatments drum seeded rice then zero till sown wheat and direct seeded rice then zero till wheat were at par with each other and recorded significantly higher yield as compared to farmers practice. These findings are in conformity with the findings of Singh et al., (2014); Bohra and Kumar (2015).

\section{Soil moisture content studies}

In general, the profile moisture content was highest at the time of sowing $(21 \%)$ and it was lowest at the time of crop maturity in all the treatments (Table 4). The increases in profile moisture content are visible from the peaks under tillage practices, difference were because of moisture conserved due to the application of irrigation. The moisture content of conventional tilled plots $\left(T_{1}\right)$ was always lower than zero and reduced tillage plots during the year of study except in the peaks where the moisture content in the profile was always same due to recharging of profile by application of irrigation. In between the season the lowest soil moisture content in conventional tillage crop and rotavator till plots was 51 DAS (14.8\%), 73 DAS (14.2\%) and 102 DAS (13.3\%) respectively. The conventional till crop under all the irrigation application management kept the average profile soil moisture content $1.5 \%$ lower than zero tillage plots throughout the crop season except after recharging the soil profile either by application of irrigation or by rainfall. The crop water use increased markedly in conventional till plots $\left(\mathrm{T}_{1}\right)$ than zero till plots during the year of study. Maximum WUE was recorded under $\mathrm{T}_{2}$ PDSR -ZTW followed by $\mathrm{T}_{5}$ UMTPR- RTW, $\mathrm{T}_{4}$ UMTPR-ZTW and $\mathrm{T}_{3}$ DSR-ZTWROT during the year of experimentation. The WP was remarkably low in conventional till plots crop than zero and reduced till crop plots during both the year of study. The highest moisture depletion under the conventional method might be due to less availability of moisture at upper layer and more evaporation from upper surface. Similar results have been reported by Zaman et al., (2006); Naresh et al., (2013a) and Ram et al., (2013).

\section{Profitability}

Maximum system net return (Rs. 969613/ha) and highest $\mathrm{B}: \mathrm{C}$ ratio (3.05) recorded in the rice $\mathrm{T}_{3}$ (DSR) - wheat (ZT) followed by rice $\mathrm{T}_{2}$ (DMS) - wheat (ZT) and rice $\mathrm{T}_{4}$ (UPMTP) - wheat (ZT) crop establishment methods, respectively (Table 3 ). This may be because of higher water use efficiency than other tillage establishment practices as well as comparatively higher increase in grain yield than in other treatment. Treatment $\mathrm{T}_{3}$ was recorded Rs. 24485/ha higher net return over $\mathrm{T}_{1}$ conventional practices. Higher net return and $\mathrm{B}$ : $\mathrm{C}$ ratio in rice $\mathrm{T}_{3}$ (DSR) -wheat (ZT) crop establishment method attributed to lowest cost of cultivation and comparable grain yield among the different crop establishment methods tested. The negative economics and lowest $\mathrm{B}$ : $\mathrm{C}$ ratio in $\mathrm{T}_{1}$ was because of its higher cost during experimentation. Similar result was recorded by Naresh et al., (2012) and Jat et al., (2013).

Based on the results of on farm trials, it may be concluded that for getting higher yield, rice (UMTP) - wheat (ZT) was the best crop establishment method in rice - wheat cropping system. 
Table.1 Yield and yield attributes of rice as affected by crop establishment methods. (Pooled data of 3 years)

\begin{tabular}{|c|c|c|c|c|c|}
\hline Treatments & $\begin{array}{l}\text { Effective } \\
\text { tillers } / \mathrm{m}^{2}\end{array}$ & $\begin{array}{l}\text { Grain / } \\
\text { panicle }\end{array}$ & $\begin{array}{c}1000 \text { grain } \\
\text { wt. } \\
\text { (g) }\end{array}$ & $\begin{array}{l}\text { Grain } \\
\text { yield } \\
\text { (q/ha.) }\end{array}$ & $\begin{array}{l}\% \text { increase in } \\
\text { yield over FP }\end{array}$ \\
\hline $\begin{array}{c}\text { BASTI } \\
\text { Rice }(\mathrm{CTP})-\text { wheat }(\mathrm{CS}) \mathrm{FP}\end{array}$ & 322 & 120 & 20.46 & 45.3 & -- \\
\hline Rice (DMS) - wheat (ZT) & 357 & 126 & 19.78 & 49.2 & 4.1 \\
\hline Rice (DSR) - wheat (ZT) & 301 & 110 & 18.23 & 46.3 & 0.2 \\
\hline Rice(UPMTP) - wheat (ZT) & 333 & 118 & 18.63 & 47.6 & 2.9 \\
\hline Rice (PMTP) - wheat (RTV) & 327 & 117 & 20.35 & 46.4 & 0.2 \\
\hline $\begin{array}{c}\mathrm{CD}(P=0.05) \\
\text { Gorakhpur }\end{array}$ & 16 & 5 & NS & 2.4 & \\
\hline Rice $(\mathrm{CTP})$ - wheat (CS) FP & 318 & 125 & 20.7 & 45.5 & - \\
\hline Rice (DMS) - wheat (ZT) & 355 & 134 & 19.1 & 50.7 & 11.4 \\
\hline Rice (DSR) - wheat (ZT) & 310 & 127 & 18.6 & 48.1 & 1.31 \\
\hline Rice(UPMTP) - wheat (ZT) & 354 & 129 & 18.2 & 48.2 & 5.9 \\
\hline Rice (PMTP) - wheat (RTV) & 334 & 125 & 20.5 & 49.8 & 9.5 \\
\hline $\mathrm{CD}(P=0.05)$ & 18 & 6 & NS & 2.6 & \\
\hline $\begin{array}{c}\text { Siddharthnagar } \\
\text { Rice(CTP) - wheat (CS) FP }\end{array}$ & 310 & 118 & 20.6 & 44.6 & - \\
\hline Rice (DMS) - wheat (ZT) & 375 & 139 & 20.1 & 52.6 & 25.7 \\
\hline Rice (DSR) - wheat (ZT) & 350 & 129 & 18.8 & 49.2 & 10.7 \\
\hline Rice(UPMTP) - wheat (ZT) & 359 & 134 & 18.6 & 50.8 & 19.3 \\
\hline Rice (PMTP) - wheat (RTV) & 365 & 135 & 20.6 & 52.4 & 22.9 \\
\hline $\mathrm{CD}(P=0.05)$ & 17 & 8 & NS & 2.7 & \\
\hline
\end{tabular}


Table.2 Yield and yield attributes of wheat as affected by crop establishment methods. (Pooled data of 3 years)

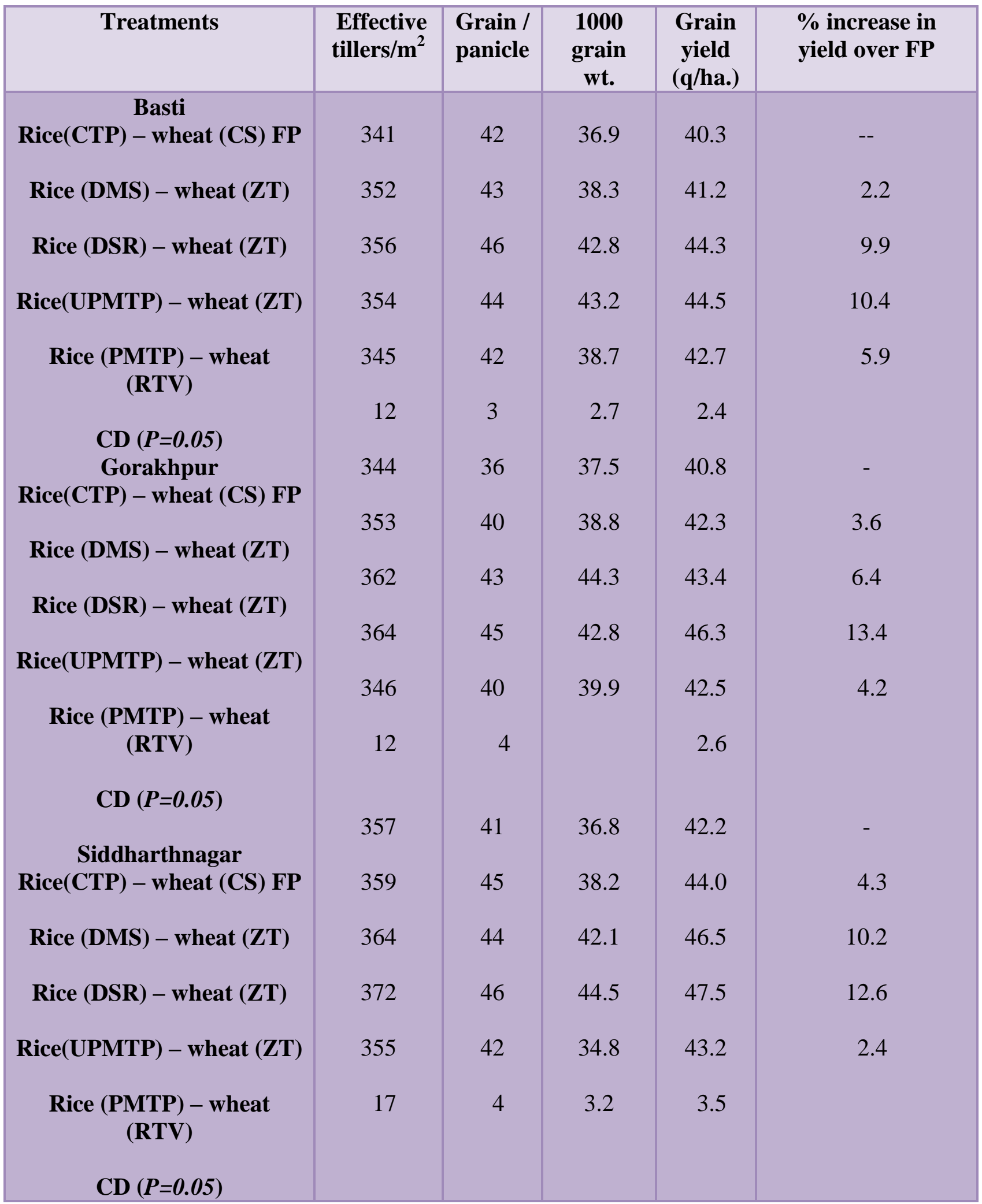


Table.3 Rice equivalent yield, economics and nutrient uptake of rice - wheat cropping system as affected by crop establishment methods (Pooled data of 3 years of 3 district)

\begin{tabular}{|c|c|c|c|c|c|c|c|}
\hline $\begin{array}{l}\text { Rice equivalent yield, economics } \\
\text { and nutrient uptake of rice - } \\
\text { wheat cropping } \\
\text { system as affected by crop } \\
\text { establishment methods (Pooled } \\
\text { data of } 3 \text { years of } 3 \text { district) } \\
\text { Treatments }\end{array}$ & $\begin{array}{l}\text { REY } \\
(q / h a)\end{array}$ & $\begin{array}{c}\text { Cost of } \\
\text { cultivation } \\
\text { (Rs./ha) }\end{array}$ & $\begin{array}{c}\text { Net } \\
\text { return } \\
\text { (Rs. /ha) }\end{array}$ & $\begin{array}{l}\mathrm{B}: \mathrm{C} \\
\text { ratio }\end{array}$ & $\begin{array}{l}\text { upt } \\
\mathrm{N}\end{array}$ & $\begin{array}{l}\text { Uutri } \\
\text { ke(K } \\
P\end{array}$ & $\begin{array}{l}\text { t } \\
\text { /ha) } \\
\mathrm{K}\end{array}$ \\
\hline $\operatorname{Rice}(\mathrm{CTP})$ - wheat $(\mathrm{CS}) \mathrm{FP}$ & 90.43 & 61000 & 72476 & 1.86 & 189 & 91 & 215 \\
\hline Rice (DMS) - wheat (ZT) & 97.67 & 48200 & 95970 & 2.53 & 206 & 99 & 232 \\
\hline Rice (DSR) - wheat (ZT) & 97.19 & 46500 & 96961 & 2.47 & 192 & 94 & 217 \\
\hline Rice(UPMTP) - wheat (ZT) & 99.73 & 52800 & 94357 & 2.35 & 209 & 99 & 234 \\
\hline Rice (PMTP) - wheat (RTV) & 96.73 & 55300 & 87483 & 2.19 & 201 & 97 & 229 \\
\hline $\mathrm{CD}(P=0.05)$ & 06.12 & & & & 13 & 4 & 11 \\
\hline
\end{tabular}

Table.4 Soil moisture content at different crop stages before recharging soil profile as influenced by planting pattern in rice-wheat system

\begin{tabular}{|c|c|c|c|c|c|c|c|c|}
\hline \multirow[t]{2}{*}{ Treatments } & \multicolumn{5}{|c|}{ Soil moisture content $(\%)$} & \multirow{2}{*}{$\begin{array}{l}\text { Total soil } \\
\text { moisture } \\
\text { depletion }\end{array}$} & \multicolumn{2}{|c|}{$\begin{array}{l}\text { Water use efficiency } \\
\left(\mathrm{q} \mathrm{ha} \mathrm{ha}^{-1} \mathrm{~cm}\right)\end{array}$} \\
\hline & $21 \mathrm{DAS}$ & $\begin{array}{l}39 \\
\text { DAS }\end{array}$ & $\begin{array}{l}51 \\
\text { DAS }\end{array}$ & $\begin{array}{l}73 \\
\text { DAS }\end{array}$ & $102 \mathrm{DAS}$ & & Rice & Wheat \\
\hline $\mathrm{T}_{1}$ CTPR -CSW & 14.6 & 16.6 & 15.3 & 14.2 & 13.8 & 12.7 & 1.81 & 2.89 \\
\hline $\mathrm{T}_{2}$ PDSR -ZTW & 15.6 & 16.8 & 15.3 & 14.5 & 14.0 & 11.3 & 2.14 & 3.33 \\
\hline $\mathrm{T}_{3}$ DSR-ZTW & 16.1 & 17.3 & 15.7 & 14.9 & 14.4 & 12.8 & 1.92 & 2.74 \\
\hline $\begin{array}{c}\mathrm{T}_{4} \text { UMTPR- } \\
\text { ZTW }\end{array}$ & 14.2 & 16.5 & 15.5 & 14.2 & 13.8 & 14.8 & 1.96 & 2.86 \\
\hline $\begin{array}{c}\mathrm{T}_{5} \text { UMTPR- } \\
\text { RTW }\end{array}$ & 13.3 & 16.2 & 15.0 & 13.8 & 13.5 & 12.2 & 2.02 & 3.12 \\
\hline Mean & 14.6 & 16.6 & 15.3 & 14.2 & 13.8 & 12.6 & - & - \\
\hline
\end{tabular}

For getting highest net return /ha/year and $\mathrm{B}$ : $\mathrm{C}$ ratio rice (DSR) - wheat $(\mathrm{ZT})$ may be the best crop establishment method which can minimize the cost of cultivation and improve the soil health under Tarai belt of Eastern Uttar Pradesh.

\section{References}

Anonymous, Directorate of Economics and Statistics, Department of Agriculture and Cooperation, Ministry of Agriculture and Farmer's Welfare. Govt. of India, 2016. 
Bhatt, R., AND Kukal, S.S. 2015. Soil moisture dynamics during intervening period in rice-wheat sequence as affected by different tillage methods at Ludhiana, Punjab, India. Soil Environ, 34(1): 82-88.

Bohra, J.S., and Kumar, R. 2015. Effect of crop establishment methods on productivity, profitability and energetics of rice (Oryza sativa)-wheat (Triticum aestivum) system. Indian J Agri Sci., 85(2): 217-230.

Das, A., Lal, R., D. Patel, R. Idapuganti, J. Layek, S. Ngachan, P. Ghosh, J. Bordoloi, M. Kumar. 2014. Effects of tillage and biomass on soil quality and productivity of lowland rice cultivation by small scale farmers in North Eastern India. Soil Tillage Res, 143: 50-58.

Derpsch R, Franzluebbers AJ, Duiker SW, Reicosk DC, Koeller K, Friedrich T, et al., 2014. Why do we need to standardize no-tillage research? Soil Tillage Res. 137: 16-22.

Jat, M. L., Gathala, M. K., Ladha, J. K., Saharawat, Y. S., Jat, A. S., Vipin, Kumar, Sharma, S. K., Kumar, V., and Gupta, R. K. 2009. Evaluation of precision land levelling and double zero-till systems in the rice-wheat rotation: Water use, productivity, profitability and soil physical properties. Soil Tillage Res. 105, 112 121.

Jat, M.L., Gathala, M.K., Saharawat, Y.S., Tetarwale, J.P., Gupta, Raj and Singh, Yadvinder 2013. Double no-till and permanent raised beds in maize-wheat rotation of north-western Indo-Gangetic plains of India: Effects on crop yields, water productivity, profitability and soil physical properties. Field Crops Res. 149: 291-299.

Kurothe, R.S., G. Kumar, R. Singh, H.B. Singh and S.P. Tiwari et al., 2014. Effect of tillage and cropping systems on runoff, soil loss and crop yields under semiarid rain-fed agriculture in India. Soil Tillage Res. 140: 126-134.

Mishra J V P, Bhanu C and Subrahmanyam D.2012. Crop establishment, tillage and weed management techniques S, Singh on weed dynamics and productivity of rice (Oryza sativa)-chickpea (Cicer arietinum) cropping system. Indian $J$ Agri Sci, 82(1): 15-20.

Naresh, R.K., Singh, S.P. and Kumar, Vineet. 2013a. Crop establishment, tillage and water management technologies on crop and water productivity in rice-wheat cropping system of North West India. Int J Sci Life Sci Biotech Pharma Res. 10:1-12.

Naresh, R. K., Singh, S. P., Singh, A., Kamal, Khilari, Shahi, U. P. and Rathore, R. S. 2012. Evaluation of precision land leveling and permanent raised bed planting in maize-wheat rotation: productivity, profitability, input use efficiency and soil physical properties. Indian J. Agri. Sci., 105(1): 112-121.

Ram, H., Dadhwal, V., Vashist, K. K., Kaur, H. 2013. Grain yield and water use efficiency of wheat (Triticum aestivum L.) in relation to irrigation levels and rice straw mulching in North West India. Agric Water Management 128: 92-101.

Saharawat, Y.S., Singh, B, Malik, RK, Ladha, JK, Gathala, M, Jat, ML and Kumar, V. 2010. Evaluation of alternative tillage and crop establishment methods in a rice- wheat rotation in North Western IGP. Field Crop Res, 116: 260-267, 2010.

Sharma, P.C., Jat, HS, Kumar, V, Gathala, MK, Datta, A, Yaduvanshi, NPS, Choudhary, M, Sharma, S, Singh, LK, Saharawat, Y, Yadav, AK, Parwal, A, Sharma, DK, Singh, G, Jat, ML, Ladha, JK and and McDonald. 2015. A 
Sustainable Intensification Opportunities under Current and Future Cereal Systems of North-West India. Technical Bulletin: CSSRI/Karnal/ 2015/4. Central Soil Salinity Research Institute, Karnal. Pp. 46.

Singh, S.N., Sah, A.K., Om Prakash, Singh, R.K., Singh, V.K. 2010.Assessing the impact of zero tilled wheat growing in rice (Oryza sativa L.)-wheat (Triticum aestivum L.) cropping systems the case of central Uttar Pradesh in the IndoGangetic Plain. Outlook on Agriculture. 39(3): 197-202.

Zaman, A., Nath, R. and Chaudharu, S. K.2006. Evapotranspiration, water use efficiency, moisture extraction pattern and seed yield of wheat as influenced by irrigation and nitrogen under limited moisture supply condition. Indian Agriculturist, 51(1/2): 19-23.

\section{How to cite this article:}

Tomar, S.K., S.N. Singh, A.P. Rao, R.K. Naresh, V.K. Sharma, Sudhanshu Singh, S.K. Bargaha, Shailesh K. Singh, Ashok Pandey, J.P. Singh and Singh, R.V. 2019. Influence of Crop Establishment Methods on Crop Water Productivity and Profitability in Rice-Wheat Systems under Eastern Indo Gangetic Plains. Int.J.Curr.Microbiol.App.Sci. 8(06): 259-268. doi: https://doi.org/10.20546/ijcmas.2019.806.029 